\title{
Unintended Learning in Primary School Practical Science Lessons from Polanyi's Perspective of Intellectual Passion
}

\author{
Jisun Park ${ }^{1} \cdot$ Jinwoong Song ${ }^{1} \cdot$ Ian Abrahams ${ }^{2}$
}

Published online: 13 November 2015

(C) The Author(s) 2015. This article is published with open access at Springerlink.com

\begin{abstract}
This study explored, from the perspective of intellectual passion developed by Michael Polanyi, the unintended learning that occurred in primary practical science lessons. We use the term 'unintended' learning to distinguish it from 'intended' learning that appears in teachers' learning objectives. Data were collected using video and audio recordings of a sample of twenty-four whole class practical science lessons, taught by five teachers, in Korean primary schools with 10- to 12-year-old students. In addition, video and audio recordings were made for each small group of students working together in order to capture their activities and intra-group discourse. Pre-lesson interviews with the teachers were undertaken and audio-recorded to ascertain their intended learning objectives. Selected key vignettes, including unintended learning, were analysed from the perspective of intellectual passion developed by Polanyi. What we found in this study is that unintended learning could occur when students got interested in something in the first place and could maintain their interest. In addition, students could get conceptual knowledge when they tried to connect their experience to their related prior knowledge. It was also found that the processes of intended learning and of unintended learning were different. Intended learning was characterized by having been planned by the teacher who then sought to generate students' interest in it. In contrast, unintended learning originated from students' spontaneous interest and curiosity as a result of unplanned opportunities. Whilst teachers' persuasive passion comes first in the process of intended learning, students' heuristic passion comes first in the process of unintended learning. Based on these findings, we
\end{abstract}

Jinwoong Song

jwsong@snu.ac.kr

Jisun Park

js0829@snu.ac.kr

Ian Abrahams

iabrahams@lincoln.ac.uk

1 Physics Education Department, Seoul National University, 1 Gwanak-ro, Gwanak-gu, Seoul 151-742, Korea

2 School of Education, University of Lincoln, Brayford Pool, Lincoln, Lincolnshire LN6 7TS, UK 
argue that teachers need to be more aware that unintended learning, on the part of individual students, can occur during their lesson and to be able to better use this opportunity so that this unintended learning can be shared by the whole class. Furthermore, we argue that teachers' deliberate action and a more interactive classroom culture are necessary in order to allow students to develop, in addition to heuristic passion, persuasive passion towards their unintended learning.

Keywords Unintended learning · Practical work · Primary science $\cdot$ Polanyi $\cdot$ Heuristic passion

\section{Introduction}

The typical image of school learning is that students are learning what their teacher teaches (Sünkel 1996/2005). However, a close look shows that students do not always learn what their teachers intend and, in some cases, learn things that their teachers had not planned and/or intended them to learn (Marsick and Watkins 2001). The idea that, in school, students learn something in addition to what is intended by the teacher is not a new idea in the field of education. Whilst the current study focused on unintended conceptual learning, research into what was referred to as the 'hidden curriculum' (e.g. Apple 1979) has already found that there can be considerable unintended learning in terms of cultural norms, values, and ideology that were not, in themselves, intended learning outcomes of the teacher.

Although unintended learning is a rather familiar phenomenon (Marsick and Watkins 2001), it has attracted little research in science education. This is because most of science education research has tended to focus on whether students learn what the teacher intended them to learn and the effectiveness of the intended teaching and learning process. Indeed, Abrahams and Millar (2008) suggested that the effectiveness of a lesson can only be considered in terms of what the students do and learn relative to what the teacher intended them to do and learn. For this reason, previous research (Allen 2010; Chinn and Brewer 1993; Nott and Smith 1995; Rigano and Ritchie 1995) dealing with effectiveness of practical work in science classes has merely reported that the tasks are not effective in terms of teachers' intended learning objectives. For this reason, this study explored what we will refer to as unintended—to clearly distinguish this from intended-learning in science classes during practical work.

We use the term 'unintended' to describe this type of learning, rather than the more widely used 'incidental' learning (e.g. Marsick and Watkins 2001; Newton 2013; Saffran et al. 1997; Webb 2008), as we feel that it makes a clearer distinction between a teacher's intended learning objectives and outcomes (both are terms widely used in the classroom), and those outcomes and objectives that were, from the teacher's perspective, wholly unintended. The use of 'unintended', unlike 'incidental', places a greater emphasis on the fact that whilst learning might have taken place in a particular lesson it was, from the teacher's perspective, unintended. Using the model of Abrahams and Millar (2008) such a lesson cannot, in terms of that specific unintended aspect of learning, be considered effective.

Previous research has shown that much unintended learning is achieved without the learner's awareness (Marsick and Watkins 2001). This draws on Polanyi's (1958, 1967) discussion of tacit knowledge and personal commitment (Nonaka et al. 1996). Polanyi emphasized the involvement of personal commitment in the formation of knowledge. By 
doing so, he criticized the objectivity that focuses only on the propositional knowledge as a result, rather than on the process of scientific inquiry as a human endeavour. He affirmed that there is a tacit dimension of knowledge that cannot be separated from personal engagement. In addition, he argued that individual intellectual passion is not merely a psychological 'by-product' but has an important role in making scientists pursue scientific knowledge. Although Polanyi's idea on intellectual passion in science could have educational implications, only a limited attention has been given to this so far in science education (Jacobs 2000; Kim and Kim 2003). With this background, this study focuses on students' unintended learning in primary practical lessons and especially on looking for its educational values from Polanyi's perspective of intellectual passion. The research questions are as follows:

1. What conditions are needed for unintended learning to occur?

2. Can unintended learning acquired by a student be shared with other students in their class?

3. What are the educational implications of unintended learning from the perspective of intellectual passion?

\section{Structure of Knowledge and Intellectual Passion by Polanyi}

Whilst Polanyi has been influential in the philosophy of science, he remains relatively unknown within the science education community. Although he did not make explicit claims about education, his work on tacit dimension, intellectual passion and in-dwelling, can have implications for science education (Jacobs 2000). His ideas can have implications for practical work in science lessons because he emphasized personal commitment, such as intellectual passion and tacit knowledge embodied by practice (Woolnough 2001). Specifically, the notion of intellectual passion that leads scientists to pursue knowledge can become a useful means of exploring the nature and value of unintended learning in this study.

\subsection{Tacit Dimension in Knowledge and Personal Commitment}

Polanyi argued that there is a tacit dimension in knowledge by stating: 'We can know more than we can tell' (Polanyi 1967, p. 4). Tacit dimension of knowledge by Polanyi, procedural knowledge by Ryle (1949), and practical knowledge by Oakeshott (1962) share a common emphasis in terms of practice. In particular, Polanyi argued that tacit knowledge was not a separate kind of knowledge but rather a part of knowledge structure:

Now we see tacit knowledge opposed to explicit knowledge; but these two are not sharply divided. While tacit knowledge can be possessed by itself, explicit knowledge must rely on being tacitly understood and applied. Hence all knowledge is either tacit or rooted in tacit knowledge. A wholly explicit knowledge is unthinkable (Polanyi 1969, p. 144).

By arguing that all knowledge has a tacit dimension that can only be acquired by practice (Polanyi 1967), personal commitment becomes essential in pursuing knowledge.

Polanyi gave examples of tacit knowledge such as hitting a nail with a hammer:

When we use a hammer to drive in a nail, we attend to both nail and hammer, but in a different way. We watch the effect of our strokes on the nail and try to wield the hammer so as to hit the nail most effectively. When we bring down the hammer we do not feel that its handle has struck our palm but that its head has struck the nail. Yet in a sense we are certainly alert to the feelings in our palm and 
the fingers that hold the hammer. They guide us in handling it effectively, and the degree of attention that we give to the nail is given to the same extent but in a different way to those feelings. The difference may be stated by saying that the latter are not, like the nail, objects of our attention, but instruments of it. They are not watched in themselves; we watch something else while keeping intensely aware of them. I have a subsidiary awareness of the feeling in the palm of my hand which is merged into a focal awareness of my driving the nail (Polanyi 1958, p. 55).

The tacit dimension consists in that the feeling in our palm and the fingers that hold the hammer cannot be acquired without an actual experiencing in hitting the nail with a hammer. As Polanyi considered personal commitment in knowledge, he (1958) titled his book as 'personal knowledge'. Polanyi (1958) described personal commitment in scientific community as intellectual passion of scientists.

\subsection{Intellectual Passion: Heuristic and Persuasive}

Polanyi introduced 'intellectual passion' (Polanyi 1958, p. 169) to explain how knowledge could be discovered, produced, and advanced. He argued that intellectual passion is the necessary condition both for inspiring scientists to do inquiry and for subsequently sharing and explaining their discoveries with others. According to him, intellectual passion has two components: 'heuristic passion' and 'persuasive passion'. Heuristic passion functions as an inspiration to pursue knowledge, whereas, in contrast, persuasive passion functions as a driver to share that knowledge with others. Polanyi suggested that these passions are not merely a psychological by-product but have a logical function to contribute in science. The excerpt below shows that heuristic passion, such as consistent interest and effort, is crucial to solving any problem.

\footnotetext{
Obsession with one's problem is in fact the mainspring of all inventive power. Asked by his pupils in jest what they should do to become 'a Pavlov', the master answered in all seriousness: 'Get up in the morning with your problem before you. Breakfast with it. Go to the laboratory with it. Eat your lunch with. Keep it before you after dinner. Go to bed with it in your mind. Dream about it.' (Polanyi 1958, p. 127)
}

Polanyi also mentioned that heuristic passion is a mainspring of originality and/or creativity for individual scientists. Once a person discovers or produces some knowledge, it is natural that the person wants to share it with others, and this desire to share is called persuasive passion. Examples of this might include publishing papers in scientific community and teaching students in schools. Polanyi said that heuristic passion often leads to persuasive passion and this is the case for the flourishing of scientific knowledge and community. He also argued that these passions should be supported by the community.

Articulate systems which foster and satisfy an intellectual passion can survive only with the support of a society which respects the values affirmed by these passions, and a society has a cultural life only to the extent to which it acknowledges and fulfils the obligation to lend its support to the cultivation of these passions (Polanyi 1958, p. 203).

'Intellectual passion' is also relevant in science education in the sense that heuristic passion functions as an inspiration to pursue knowledge in the classroom and persuasive passion functions as a driver for students to share what they have learnt (either intentionally or unintentionally) with other students in their class. Heuristic passion is more complicated than just curiosity or interest but, within an educational context, students' own curiosity or interest is an example of heuristic passion that students can present. In this sense heuristic passion, which encompasses a students' own curiosity and interest, can itself be seen to be an integral component in what Hidi and Harackiewicz (2000) refer to as personal interest which, it has been claimed (Abrahams 2009), is an important component of effective 
science learning. Persuasive passion can manifest itself in an educational context in terms of both a teacher's passion for teaching (Carbonneau et al. 2008) and a student's desire to share his/her learning or knowledge with other students in their class and/or their teacher. Indeed, it has been suggested (McNeill et al. 2006; Osborne et al. 2004) that this form of persuasive passion is a form of argumentation and scientific explanation. In this sense, we would suggest that a lesson needs to be an interplay between the heuristic and persuasive passions, of both students and their teacher, in order to maximize the effectiveness of any learning_including unintended learning.

\section{Method}

\subsection{Context and Ethics}

Data for this study were collected from the science classes in four public primary schools in Korea. Korea has a highly structured and controlled National Curriculum. The textbooks and guidebooks for teachers are based on the National Curriculum. Only one kind of textbook and guidebook for teachers of primary school science have been developed and published by the government. Schools in Korea have the legal obligation to use these textbooks, and it is said that 'Schools have to use the textbook that the nation has copyright or the textbooks which are authorized and qualified by the Minister of Education' in Article 29 of the Elementary and Secondary Education Act of 2014. For these reasons, Korean primary school teachers have a strong tendency to use, often exclusively, the textbooks in their lessons (Ryu et al. 2014). Teacher participants in this study also planned their lessons based on the textbook and the guidebook for teachers. The learning objectives and experiments that teacher participants in this study actually arranged were, more or less, the same as those in the textbook and the guidebook for teachers.

As this study involved direct contact with minors, the Institutional Review Board (IRB) of Seoul National University monitored all the procedures including teacher and parental consent, as well as student assent processes and data collection. The authors orally explained all the possible ethical issues to the teacher and to students, and all the required documentations were provided to students, parents, and teacher before commencing this study. In accordance with guidelines for conducting ethical research, the authors use pseudonyms for the names of the school and for all participants in this study.

\subsection{Participants}

The number of primary schools in Korea where science is taught to different classes by a single science subject teacher, in contrast to it being taught by each classroom teacher who also teaches other subjects, is increasing year by year (Kim 2012). Given this situation, it was decided to observe both classroom and science subject teachers' science lessons. The opportunistically selected individuals included two classroom teachers and three science subject teachers who agreed to participate in this study. The number of lessons during which each teacher was observed to teach was determined on the basis of their availability and the number of science lessons that they would teach during the period of observation. This ranged from a minimum of three with Mr. Sun and Mrs. Roses to a maximum of 8 with Mr. June. 
The student participants were grade 5 and 6 students whose age ranged from 10 to 12 years. A total of 149 students gave consent to participate in this study. The overview of participants and lessons observed is presented in Table 1.

\subsection{Data Collection and Analysis}

For the data collection, a total of 24 practical science lessons, taught by five teachers, were observed by the first author. These were also audio- and video-recorded. Additional data included pre-lesson interviews with the teachers, field notes, short student memos after lessons, and post-lesson interviews with the students and teachers (see Fig. 1). For the analysis, all learning outcomes were checked against the teacher's pre-stated lesson objectives to determine whether or not the observed learning had been intended by the teacher. In this section, we describe each data source and the methods used to analyse the data.

\subsubsection{Data Collection}

3.3.1.1 Pre-lesson Interviews A pre-lesson interview was carried out with each teacher to ascertain details of the lesson to be observed. During the interview, each teacher was asked about their learning objectives of the lesson and planned procedures for the experiment (the teachers in this study explained their plan for the lesson by showing the textbook or guidebook for teachers). In the case of science subject teachers, only one prelesson interview was conducted even though they were observed teaching two lessonswhich had the same learning objectives-with the same theme for two separate classes. Therefore, a total of 17 pre-lesson interviews on 24 practical lessons were audio-recorded.

3.3.1.2 Audio and Video Recording in the Lesson A total of 24 practical science lessons, taught by the five teachers, were observed and audio- and video-recorded. In addition to whole class recordings, audio and video recordings were also made for each group of students, who consented to this study, in order to capture small group activities and students' discourses. Furthermore, sometimes a hand-held camera was used to capture the much more detailed information that fixed cameras cannot capture. Where possible, the

Table 1 An overview of participants and lessons observed

\begin{tabular}{llllll}
\hline Teacher & Teacher type & $\begin{array}{l}\text { Student grade } \\
\text { (age })\end{array}$ & $\begin{array}{l}\text { Number of } \\
\text { students }\end{array}$ & $\begin{array}{l}\text { Number of different } \\
\text { classes observed }\end{array}$ & $\begin{array}{l}\text { Total number of } \\
\text { observed lessons }\end{array}$ \\
\hline Mr. Lay & Classroom teacher & $\begin{array}{l}\text { 5th grade } \\
(10-11 \text { years })\end{array}$ & 23 & 1 & 4 lessons \\
Mrs. Yuna & $\begin{array}{c}\text { Science subject } \\
\text { teacher }\end{array}$ & $\begin{array}{l}\text { 5th grade } \\
(10-11 \text { years })\end{array}$ & $18 / 28$ & 2 & 4 lessons \\
Mr. Sun & Classroom teacher & $\begin{array}{l}\text { 5th grade } \\
(10-11 \text { years })\end{array}$ & 19 & 1 & 3 lessons \\
Mrs. Rose & $\begin{array}{c}\text { Science subject } \\
\text { teacher }\end{array}$ & $\begin{array}{l}\text { 6th grade } \\
(11-12 \text { years })\end{array}$ & 17 & 1 & 3 lessons \\
Mr. June & $\begin{array}{c}\text { Science subject } \\
\text { teacher }\end{array}$ & $\begin{array}{l}\text { 6th grade } \\
(11-12 \text { years })\end{array}$ & $18 / 26$ & 2 & 8 lessons \\
\hline
\end{tabular}




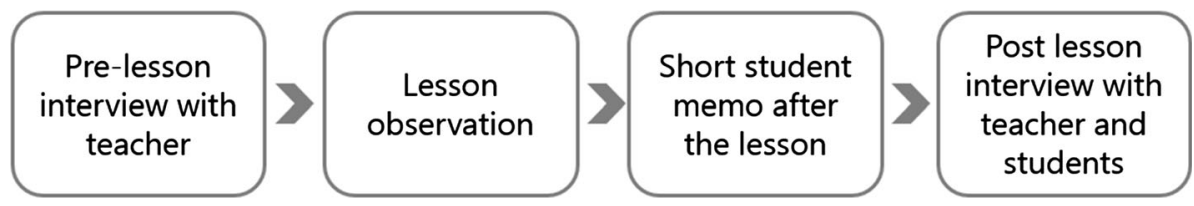

Fig. 1 Process of data collection

researcher had a conversation to confirm whether they learnt and, if so, what and how they learnt it. These conversations were audio-recorded.

3.3.1.3 Field Notes Ethnographic field notes were made, and these included details about the classroom structure, student seating arrangements, and a general description of the lesson. Field notes also have reminders of when unintended learning was observed, so that these could subsequently be examined on the video for more detail.

3.3.1.4 Short Student Memos After Lesson After the class, students were asked to write a short memo about what they had learnt in the lesson. The learning that students wrote in these memos was utilized to pick up on unintended learning in audio and video recordings. This was also one of the complementary data sources to confirm the unintended learning.

3.3.1.5 Post-lesson Interviews Post-lesson interviews with teachers and some students were also audiotaped. The students were asked what they felt they had learnt. Teachers were asked to reflect on their lessons with the aim to probe whether or not all of the observed learning had been intended by the teachers.

\subsubsection{Data Analysis}

For the data analysis, the objectives of the lesson from the pre-lesson interview were checked as the first step. The teachers' objectives, appearing in the pre-lesson interview and in the lesson, were described as 'intended learning'. Based on the intended learning, key vignettes, including cases of 'unintended learning', were identified from the video as the second step. In this study, one video of a specific group from each lesson was analysed. Unintended learning was defined as any student learning that was found to occur but had not been planned by the teacher for that specific lesson. Additional data, such as short student memos and post-lesson interviews, were then utilized to confirm it as unintended learning against intended learning. The audio data in selected vignettes were transcribed, and the conversation between a teacher and students, or among students, as well as the behaviour of the teacher and students, was analysed to understand the nature of unintended learning.

To secure the reliability of analysis of this study, member checking had been done (Guba and Lincoln 1989; Miles and Huberman 1994). The unintended learning identified in two lessons was subsequently checked with the teacher to ascertain whether what had been identified as unintended learning was also deemed as such by him/her. In both cases, the teacher confirmed that all learning identified as unintended had not actually been intended by them. 
In addition, in order to check on the reliability of the analysis, five more lessons were analysed independently by the researcher and an invited science education researcher. As a first step, two lessons were separately analysed by both researchers. Whilst the number of cases of unintended learning identified by the second researcher was larger than that of the first researcher, the second researcher's list of examples of unintended learning included all of the examples identified by the first researcher. Additional unintended learning only identified by the second researcher related to features that it was not possible to check, unambiguously, as to whether they were learnt in that specific lesson. For example, the second researcher mentioned that students seemed to learn how to negotiate with their different opinions (see Table 2). However, as we cannot tell with certainty whether they learnt this in this lesson, and the class teacher was also unable to confirm this, it was decided not to consider this as unintended learning in this study. After the researcher and the invited researcher agreed not to include such ambiguous unintended learning, three more lessons were analysed independently for examples of unintended learning and total agreement was found in all three cases. After checking for reliability, the researcher analysed the rest of the data.

Seventy-nine cases of unintended learning were identified in this study. In the four lessons delivered by Mr. Lay and Mrs. Yuna, there were 12 and 14 cases, respectively. In the three lessons delivered by Mr. Sun and Mr. Roses, there were 8 and 10 cases, respectively, with the remaining 35 examples of unintended learning being observed throughout Mr. June's eight lessons. We would like to emphasize here that the number of cases of unintended learning that we report here could be lower than the number that

Table 2 Example of unintended learning and exclusion from unintended learning

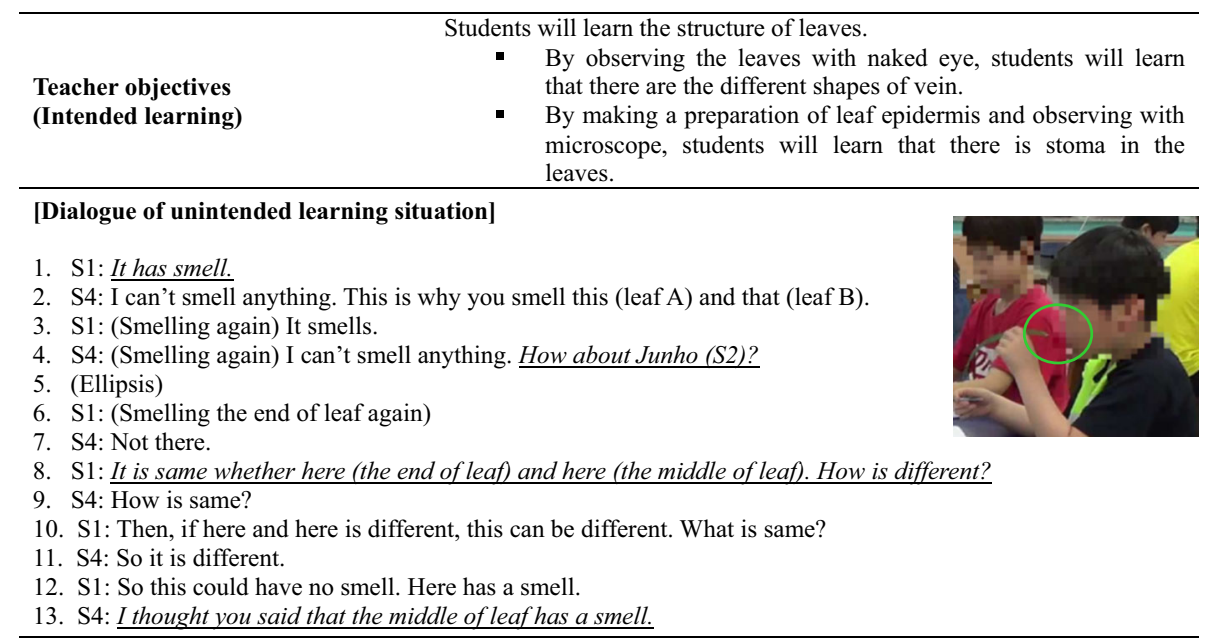

Example of unintended learning found by both researchers

Example of exclusion from unintended learning found by the invited researcher
Students learnt that the end of leaf has a smell and the middle of the leaf has no smell. (See line 1)
Students learnt that how to negotiate with their different opinions by asking for a second opinion (See line 4) other's reason (See line 8 and 13).

(Reason for exclusion: This was excluded because it was not possible to ascertain unambiguously whether the skill of negotiation had been learnt in this specific lesson) 
actually occurred. Only learning that was unambiguously unintended by the teacher was included, with cases that were considered ambiguous being excluded. In addition, any unintended learning by students who had asked to be excluded from the study, although they were in the class, was not analysed in this study.

The excerpts in the findings section were included after discussion among all three authors. The excerpts in this article were included with the deeper, self-reflective, empathetic understanding of the researchers. Also the findings of this article have been presented in conferences, and the feedback received from other academics was very positive. According to Shenton (2004), 'peer scrutiny of research', such as discussion with colleagues and presenting at conference, is one of the techniques for increased credibility in qualitative research.

\section{Findings}

\subsection{Conditions for Unintended Learning}

The first necessary condition for unintended learning that was found in this study is that students needed to express their interest. A second condition was that students' interest needed to be maintained. It also emerged that an opportunity for students to connect to their prior knowledge did, in some cases, provoke unintended learning. Examples to support the conditions for unintended learning are considered.

\subsubsection{Students Expressing Their Interest}

Most of the unintended learning observed in this study was initiated by students' spontaneous curiosity or interest. Even though all students observed a certain phenomenon, only a few of them who got interested in it were found to learn something additional to that intended by the teacher.

The task in Mr. Sun's lesson was for students to boil some leaves in alcohol for a few minutes in order to remove the chlorophyll, so that the colour of the iodine stain, when added to the leaves, could be clearly seen. All students could see that the alcohol turned green as chlorophyll was removed from the leaves. However, not all students got interested in this phenomenon. Only three out of the five groups expressed interest in the colour change of alcohol. Note that there were six groups in the class, but only the five groups who consented to participate in this study were recorded. In student memos, after lesson, 13 students mentioned that they learnt that alcohol turned green when the leaves were boiled in it.

Jangwon It has been taken something. Chlo...what was it?

Minchul Chlorophyll

Jangwon It might be Chlorophyll. That one. That was taken out of it

The above discourse in the lesson showed that unintended learning occurred to Jangwon when he was interested in colour change. He learnt that alcohol turned green when the leaves were boiled in alcohol, but also why it happened. If Jangwon had not been interested in this phenomenon, he might not have learnt that chlorophyll comes out of leaves when these are boiled in alcohol and alcohol turns green.

After Mr. June's lesson, when students were asked to write a short memo about what they learnt on that day, one student, Joohyun, noted that he had learnt that some magnets 
are very strong. This lesson was about electromagnets, and students learnt that the more wire they wrapped around the nail, the stronger the electromagnet would be. As there was no magnet in the practical work, the researcher asked him, in the post-lesson interview, how he learnt that. He answered that he learnt it not from the practical work he had done but from the students who played with neodymium magnets. In this lesson, teacher made a student who had a learning difficulty do his individual work in front of the class on his own and let him play with various magnets. Joohyun watched and noticed that the magnet his friend was playing with was able to attract most of the objects around him, and learnt how strong neodymium magnets are (see Fig. 2). When the researcher asked him whether he already knew this before that class, he responded that this was the first time he had seen that neodymium was attracting so many things.

Like in the example from Mr. June's lesson, if Joohyun had not been interested in the magnet that his friend played with, he might not have learnt that neodymium is strong enough to attract the steel around it.

\subsubsection{Students maintaining their interest}

Unintended learning could occur when students' interests are maintained. An example can be seen in a group from Mrs. Yuna's class, who were constructing series and parallel circuits. The students got interested in the conductivity of certain parts of the battery case, which was unlike the picture in the text book (see Fig. 3).

Sujin Look, it should be connected to here (pointing to the picture in the text book)

Minsu It is ok to connect here (part A)

Sujin Just connect here (part B)

Researcher What are you arguing about?

Aram She said it should be connected to here (part A)

Sujin We are following this and this picture says to connect here (part A) but he said to connect here (part B)

Minsu It makes electricity flow though

Sujin But it is better to follow this (textbook)

(Ellipsis)

Minsu Try it, just try it once

Teacher Two more minutes. You should complete in two minutes

(Students didn't try to connect to the part A and connected to the part B like the picture in the textbook)

As can be seen from the above discourse, Minsu wanted to try connecting the wire to part A. However, they could not try it because the teacher pushed students to complete

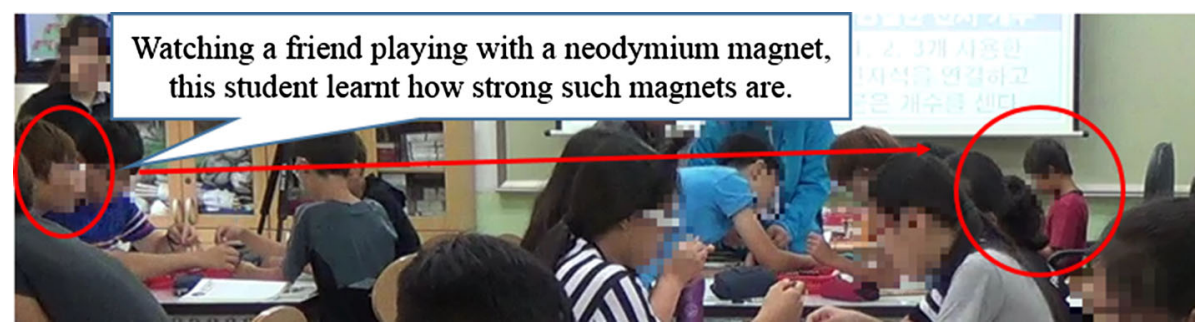

Fig. 2 Watching a friend playing with a neodymium magnet the student learnt how strong such magnets are 
Fig. 3 Parts of the battery about which students argued to connect the wire

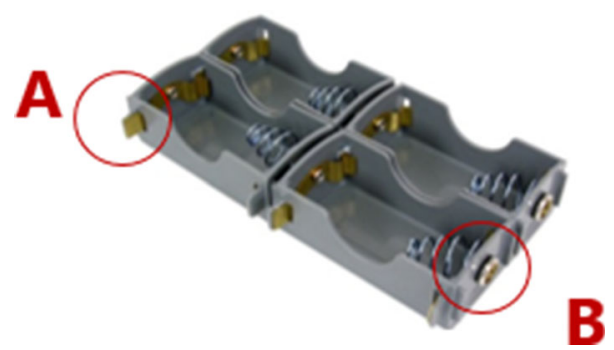

their work in two minutes. Students in this group did not try to connect the wire to part A. When students later on had more time, Sujin tried to connect the wire to part A without forgetting it.

Sujin See! When you connect here (part A), it didn't light up. It worked when you connect here (part B)

Minsu No. I will do it

(Minsu and June tried it again and it didn't light up.)

Sujin See. It doesn't work

(A few seconds later, it lighted up)

Minsu It worked!

Sujin Sorry. (You can) connect here

June Our expectation was right!

Finally, this group of students learnt, by the tests they undertook on the circuit, that connecting a wire to both part A and part B makes electricity flow. This shows that unintended learning was almost lost due to a lack of available time to explore this fully but that unintended learning did occur when the students' interest was rekindled as a result of their teacher deciding to give them more time.

\subsubsection{Connecting to Prior Knowledge}

Some cases of unintended learning were found to occur when students were able to assimilate the experience to their prior knowledge. In one case, a student examined the bulb to figure out the problem for a broken circuit, and noticed that there was a hole in the glass. The intended learning objectives in this lesson, as stated by the teacher, were that the bulb lights up when electricity flows, that the things that enable electricity to pass are called conductors, and that the things that prevent electricity passing are called nonconductors. Therefore, we could see that the broken circuit was not intended by teacher and that a student unintentionally learnt that the hole in the light bulb caused the broken circuit. A student, Jeongwoo, did not just learn the fact he observed but also connected this experience to his prior knowledge.

Jeongwoo (Looking closer at the light bulb) Teacher, isn't this light bulb supposed to be a vacuum?

Teacher (Try connecting new light bulb) Yes

Jeongwoo (Showing the light bulb) But here is a hole

Teacher (Looking at the light bulb) Where?

Jeongwoo (Showing the light bulb to the teacher) It didn't work as it was not a vacuum. A hole there 
Teacher That's fine

Jeongwoo (It seems that he is talking to the teacher but he is not looking at the teacher) There is a problem in the light bulb. All right. As there is a hole, it has not been a vacuum. Filament meets the air. The glass in the light bulb is a vacuum but it is not as there is a hole

Jeongwoo mumbled to himself that he thought that the hole in a glass bulb caused the filament to oxidize and break. He tried to make this experience sensible by grounding it on his prior knowledge. In the post-lesson interview, we found that he had anchored the idea from the book he read previously to make it sensible.

Researcher Do you remember the broken bulb in your group?

Jeongwoo Yes. It has to be a vacuum but it wasn't. It didn't work because the filament was exposed to the air too much

Researcher What happens when the filament is exposed to the air?

Jeongwoo The filament is oxidized and cut off or weakened, so it cannot light up

Researcher How did you know this? Did you see it or did you guess?

Jeongwoo I saw this in the book

Jeongwoo It says the filament is oxidized when it meets the air. So I thought the hole makes the air come in and makes it oxidised and cut off...

This student drew on his recollection, from the book that he had previously read, that a light bulb contains a vacuum in order to prevent the oxidization of the filament and applied this to explain the phenomenon he observed. This example also shows an example of meaningful learning, as Ausubel (2000) and Ausubel et al. (1968) have suggested that occurs when a student is able to connect the new information to the relevant idea in the particular learner's cognitive structure.

\subsection{Sharing individuals' unintended learning with a whole class}

Most cases of unintended learning in this study remained either with the individual student or within a small group. This was either because the teacher was unaware of the unintended learning occurring or chose to ignore it. Although students often called upon teachers with curiosity or joy when they discovered or learnt something, the teachers often responded to this with indifference and provided little specific feedback on students' discovery. This might have been caused by a teacher's sense of obligation to complete what had been planned in a given time. An example of a teacher's reaction to the unintended learning in the lesson about observing the two different leaves is presented below. A student, Jina, mentioned in the short memo that we asked her to write down after the lesson that she learnt that something sticky came out of the leaf when she peeled it. However, in video analysis, we found that the teacher gave an indifferent response to Jina on what she found and her question.

(In group activity of observing the two different leaves)

Jina What is this sticky thing? Hyun, what is this sticky thing?

(Hyun is trying touching.)

Jina Teacher, what is this sticky thing?

Teacher (Without looking at it) Write it down. Don't know what it is, write it down 
As the learning objective of this task planned by the teacher was the different shape of the leaves, such as the netted and parallel venation, he mostly responded to what he intended to teach in the group activity. Even in a whole class discussion, the teacher focused on what he intended students to observe with some guiding questions as below.

Teacher Did you find the critical differences between leaves of spiderwort and garden balsam?

Student(s) Long. Spiderwort is long

Teacher Spiderwort is long and garden balsam is a bit rounded

Teacher And when you look closer to the leaf, don't you see something that looks vaguely like a string?

Students Yes

However, in Mrs. Rose's class a situation was observed in which unintended learning within a small group was shared with the whole class. In this case, Mrs. Rose noticed that students had found that the glass cleaner was neutral or slightly acidic. Her intention had been for students to learn that the glass cleaner was alkaline. A group of students told the teacher that they had found that it was neutral, and they had noticed that the phenomenon that they observed might not be what their teacher had expected them to observe. Mrs. Rose told the students to write down the result they had when they were performing the task. During the subsequent whole class discussion, Mrs. Rose explained to the whole class the intended learning, i.e. that the glass cleaner was supposed to be alkaline. Rather than ignoring this unintended learning, in the following lesson she brought two different kinds of glass cleaner, one for house windows and the other for car windows. She explained to students that the glass cleaner that they used in their previous lesson was for car windows. She showed them that the glass cleaner for house windows is indeed alkaline, i.e. with $\mathrm{pH}$ 10 , whilst that for cars, as they had learnt, is neutral or slightly acidic so as not to damage the coating of the car window (Fig. 4).

\section{Interpreting the Unintended Learning from the Perspective of Polanyi}

In this section, we interpret our findings from the perspective of Polanyi's concept of intellectual passion. In this study, unintended learning was initiated by a student's heuristic passion, in contrast to intended learning that was initiated by the teacher's
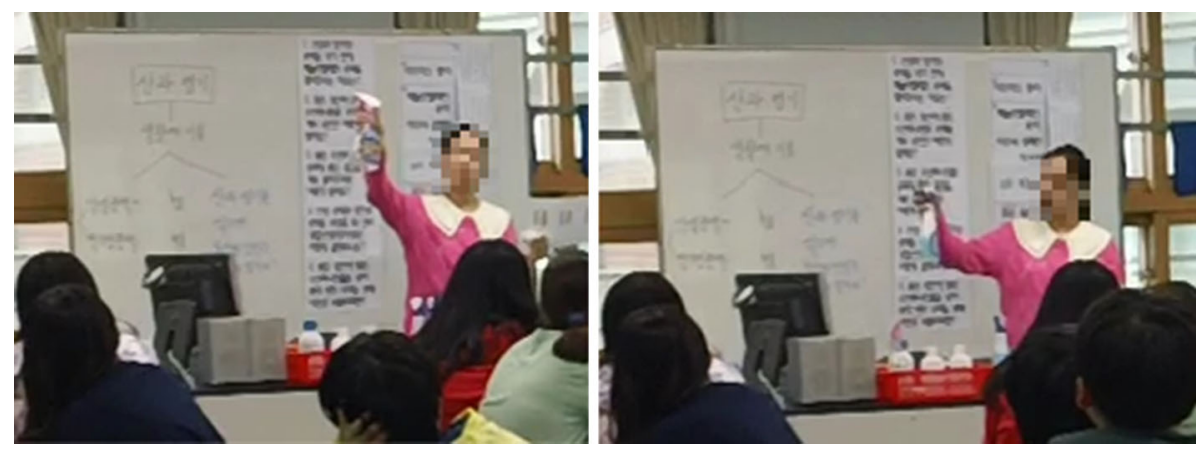

Fig. 4 Teacher sharing a small group's unintended learning with the whole class 
persuasive passion. As mentioned above, unintended learning occurred when students expressed and maintained their interest. When they became interested in a certain experience or phenomenon, students in this study mostly learnt procedural knowledge or factual knowledge by describing what they observed or experienced. Furthermore, when they had appropriate prior knowledge, their heuristic passion led students to explore the conceptual connection between the fact that students observed and their prior knowledge. For instance, a student in this study tried to explain why the broken bulb was not working based on the book he had previously read. However, intended learning takes place through a different process from that of unintended learning (see Fig. 5). For intended learning, teachers' persuasive passion comes first and students' heuristic passion follows. Teachers usually spend time in planning what and how to teach for students' effective learning (Abrahams and Millar 2008). This reflects teachers' persuasive passion to make students learn something valuable. We are not suggesting that all teachers in this study taught in a manner that was equally full of persuasive passion; however, all of their teaching was initiated by their persuasive passion for knowledge. When teachers' persuasive passion is successful, it leads to the generation of students' heuristic passion. Therefore, the process of unintended learning in which students' heuristic passion comes first is similar to the process of how scientists discover and construct knowledge. In this respect, unintended learning can give students opportunities to experience what science and authentic inquiry is.

Polanyi (1958) suggested that all scientists come to construct knowledge with their heuristic passion, often leading to persuasive passion through which they want to share their knowledge with others. He also suggested that heuristic passion not only often leads to persuasive passion, but also has to lead to that. Just like scientists' persuasive passion comes after their heuristic passion, it was observed that students also wanted to share what they found out and learnt during the lesson. However, it was found that persuasive passion for their unintended learning was often limited in the lesson. Much unintended learning remained restricted to individual students who discovered it or, if that student was working within a small group, to the individuals within that group. However, one case of unintended learning within a small group that was shared with the whole class was observed in this study indicates that opportunities for students' unintended learning can be given in the lesson.

Intended learning

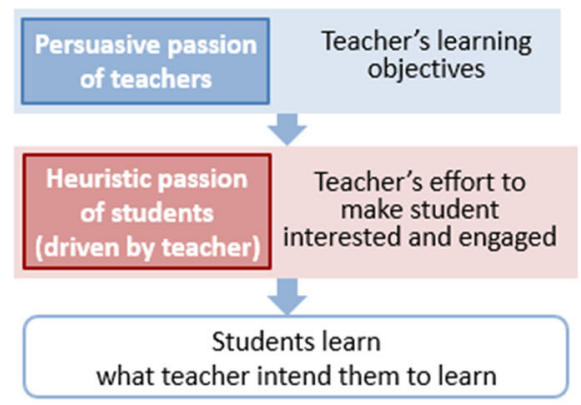

Unintended learning

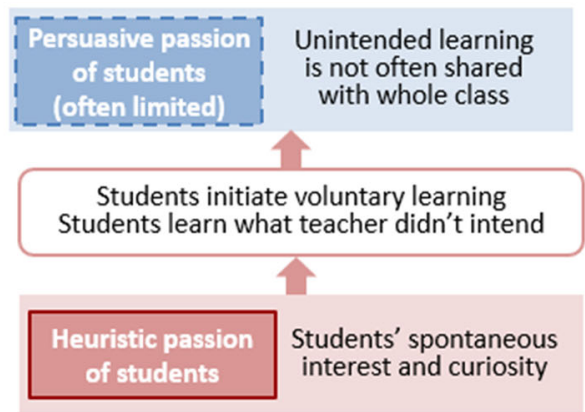

Fig. 5 Process of intended and unintended learning in the lesson 


\section{Summary and Implications}

In this study, we found that students learnt not only what their teacher intended them to learn, but also things that their teacher did not intend them to learn. Even though it is a widely accepted phenomenon, this unintended learning has not been discussed in detail within science education research. This study explored how unintended learning occurred during lessons and the educational implications of such learning from the perspective of Polanyi's (1958) intellectual passion.

It was concluded that unintended learning could begin when students got interested in something in the first place and that unintended learning finally occurred when students' interest was maintained. In addition, it was found that students were, in some situations, able to link an unintended learning experience to prior scientific knowledge. From the perspective of intellectual passion, this suggests that unintended learning arose from heuristic passion in the sense that it was driven by students' interest and curiosity. However, it was found that most unintended learning observed in this study remained restricted to individual students or to the small group of students who worked with that individual student. It was observed that teachers often responded indifferently to examples of unintended learning, either by ignoring them due to time limitations or by failing to notice that they had occurred. Given the power dynamics within the classroom, students who had learnt something unintended were, in most cases, unable to share their learning with the whole class in a manner that would have made their heuristic passion lead to persuasive passion.

From the perspective of intellectual passion, it was found that students' and teachers' intellectual passion manifested itself in a different order. In the case of intended learning, it was observed that the teacher's persuasive passion was the initiator of the learning process, with the teacher trying to generate heuristic passion for the scientific knowledge among their students. However, unintended learning comes from students' initial heuristic passion, and this then leads to their persuasive passion as they want to share their learning with their peers. In addition, unintended learning can be an opportunity to expand authentic inquiry as the process of learning has similarities with the way scientists work. Cases from the history of science, such as the unintentional discovery of penicillin, also encourage the importance of unintended learning in the class (Lenox 1985; Roberts 1989). Similarly, Louis Pasteur said that 'Chance favors the prepared mind' (1954). Alexander Fleming's discovery of penicillin did not depend solely on his luck but from his prepared scientific mind. It implies that the classroom culture of active interaction is important in order not to miss the opportunity for unintended learning.

However, in reality, students are often under pressure to achieve success in school, which means getting good grades on tests (Mulvenon et al. 2005). Moreover, teachers also feel pressured about teaching the canonical knowledge effectively, due to increased accountability of assessments such as national tests or the Trends in International Mathematics and Science Study (TIMSS) (Jones and Buntting 2013). For these reasons, there is pressure on both students and teachers not to pay attention to unintended learning that arises from their own curiosity and imagination during a science lesson. In such a classroom culture, students might give up on exploring what they found or learnt that seems irrelevant to the lesson objectives, in order to meet the teachers' expectations or to get good grades. If sufficient time and even a small positive feedback on their unintended learning were given to students in the lesson, they might not end up becoming like race horses with blinders put on next to their eyes for running forward only. 
In addition, more practical implications for teachers can be suggested in this study. One is that teachers can utilize the moment of unintended learning as a bridge to the most natural way of authentic inquiry in a school science curriculum for all. Currently, the Korean national curriculum for elementary science includes 'open scientific inquiry' that enables students to choose the topic, conduct the research, and finally present their result. However, research has shown that teachers and students have difficulties in 'open scientific inquiry' activity (Baek et al. 2015; Lee et al. 2010; Shin and Kim 2010). In particular, it has been reported that one of the most difficult things was choosing the topic for open scientific inquiry (Shin and Kim 2010). In this sense, teachers can help by encouraging an unintended moment for learning to be extended to a moment for choosing a topic of open inquiry so that students might feel confident in launching scientific inquiry.

The other practical implication is to give an opportunity to students' persuasive passion about their unintended learning. As mentioned above, unintended learning remained with the individual or within a small group. This is because students' persuasive passion of unintended learning was often limited in the lesson. Like Mrs. Rose in this study, unintended learning within a small group could be shared by teachers' persuasive passion. Furthermore, teachers' deliberate action to give opportunity for students' persuasive passion to be shared can be possible. For instance, teachers can have the time to share unintended learning at the end of the lesson in brief or teachers can utilize the internet bulletin board that all the students can access for sharing unintended learning in order to overcome the limited resources.

Acknowledgments This work was supported by the National Research Foundation of Korea Grant funded by the Korean Government (NRF-2013S1A3A2042832).

Conflict of interest The author's do not have any conflict of interest.

Open Access This article is distributed under the terms of the Creative Commons Attribution 4.0 International License (http://creativecommons.org/licenses/by/4.0/), which permits unrestricted use, distribution, and reproduction in any medium, provided you give appropriate credit to the original author(s) and the source, provide a link to the Creative Commons license, and indicate if changes were made.

\section{References}

Abrahams, I. (2009). Does practical work really motivate? A study of the affective value of practical work in secondary school science. International Journal of Science Education, 31(17), 2335-2353.

Abrahams, I., \& Millar, R. (2008). Does practical work really work? A study of the effectiveness of practical work as a teaching and learning method in school science. International Journal of Science Education, 30(14), 1945-1969.

Allen, M. (2010). Learner error, affectual stimulation, and conceptual change. Journal of Research in Science Teaching, 47(2), 151-173.

Apple, M. (1979). Ideology and curriculum. London: Routledge \& Kegan Paul.

Ausubel, D. (2000). The acquisition and retention of knowledge: A cognitive view. Dordrecht: Kluwer.

Ausubel, D. P., Novak, J. D., \& Hanesian, H. (1968). Educational psychology: A cognitive view (2nd ed.). New York: Holt, Rinehart and Winston.

Baek, J.-Y., Lim, C.-S., \& Kim, J.-Y. (2015). Elementary school students' perceptions on free science inquiry activities applying a brain-based evolutionary approach. Elementary Science Education, 34(1), $109-122$.

Carbonneau, N., Vallerand, R. J., Fernet, C., \& Guay, F. (2008). The role of passion for teaching in intrapersonal and interpersonal outcomes. Journal of Educational Psychology, 100(4), 977-987. 
Chinn, C. A., \& Brewer, W. F. (1993). The role of anomalous data in knowledge acquisition: A theoretical framework and implications for science instruction. Review of Educational Research, 63(1), 1-49.

Guba, E. G., \& Lincoln, Y. S. (1989). Fourth generation evaluation. Newbury Park: Sage.

Hidi, S., \& Harackiewicz, J. M. (2000). Motivating the academically unmotivated: A critical issue for the 21st century. Review of Educational Research, 70(2), 151-179.

Jacobs, S. (2000). Michael Polanyi on the education and knowledge of scientists. Science \& Education, 9(3), 309-320.

Jones, A., \& Buntting, C. (2013). International, national and classroom assessment: Potent factors in shaping what counts in school science. In D. Corrigan, R. Gunstone, \& A. Jones (Eds.), Valuing assessment in science education: Pedagogy, curriculum, policy (pp. 33-54). Dordrecht: Springer.

Kim, H. (2012). An analysis on the perception of teachers and the operating status in a science exclusive system in elementary school. Master thesis, Graduate School of Seoul National University of Education

Kim, M., \& Kim, B. (2003). Focused on Michael Polanyi's epistemology: A study on the objectivity of scientific knowledge. Journal of Korean Association for Science Education, 23(1), 100-116.

Lee, K.-H., Jee, K.-J., \& Park, J.-W. (2010). Investigation of elementary school teachers' recognition about open scientific inquiry. Teacher Education Research, 49(1), 71-87.

Lenox, R. S. (1985). Educating for the serendipitous discovery. Journal of Chemical Education, 62(4), 282-285.

Marsick, V. J., \& Watkins, K. E. (2001). Informal and incidental learning. New Directions for Adult and Continuing Education, 2001(89), 25-34.

McNeill, K. L., Lizotte, D. J., Krajcik, J., \& Marx, R. W. (2006). Supporting students' construction of scientific explanations by fading scaffolds in instructional materials. The Journal of the Learning Sciences, 15(2), 153-191.

Miles, M. B., \& Huberman, A. M. (1994). Qualitative data analysis: An expanded sourcebook. California: Sage.

Mulvenon, S. W., Stegman, C. E., \& Ritter, G. (2005). Test anxiety: A multifaceted study on the perceptions of teachers, principals, counselors, students, and parents. International Journal of Testing, 5(1), 37-61.

Newton, J. (2013). Incidental vocabulary learning in classroom communication tasks. Language Teaching Research, 17(2), 164-187.

Nonaka, L., Takeuchi, H., \& Umemoto, K. (1996). A theory of organizational knowledge creation. International Journal of Technology Management, 11(7-8), 833-845.

Nott, M., \& Smith, R. (1995). 'Talking your way out of it', 'rigging' and 'conjuring': What science teachers do when practicals go wrong. International Journal of Science Education, 17(3), 399-410.

Oakeshott, M. (1962). Rationalism in politics and other essays. New York: Basic Books Publication Corporation.

Osborne, J., Erduran, S., \& Simon, S. (2004). Enhancing the quality of argumentation in school science. Journal of Research in Science Teaching, 41(10), 994-1020.

Pasteur, L. (1954). Inaugural lecture as professor and dean of the faculty of science, University of Lille, Douai, France, December 7, 1854. A treasury of the world's great speeches, each speech Prefaced with its dramatic and biographical setting and placed in its full historical perspective, 856.

Polanyi, M. (1958). Personal knowledge: Towards a post-critical philosophy. Chicago: University of Chicago Press.

Polanyi, M. (1967). The tacit dimension. Garden City, NY: Anchor Books.

Polanyi, M. (1969). Knowing and being. Edited with an introduction by Marjorie Grene. Chicago: University of Chicago Press.

Rigano, D. L., \& Ritchie, S. M. (1995). Student disclosures of fraudulent practice in school laboratory. Research in Science Education, 25(4), 353-363.

Roberts, R. M. (1989). Serendipity: Accidental discoveries in science. New York: Harcourt Brace.

Ryle, G. (1949). The concept of mind. London: Hutchinson.

Ryu, Y., Choi, R., \& Kim, D. (2014). A study on the process of unified instructions in Korean Elementary school based on grounded theory. The Journal of Yeolin Education, 22(4), 279-299.

Saffran, J. R., Newport, E. L., Aslin, R. N., Tunick, R. A., \& Barrueco, S. (1997). Incidental language learning: Listening (and Learning) out of the corner of your ear. Psychological Science, 8(2), 101-105.

Shenton, A. K. (2004). Strategies for ensuring trustworthiness in qualitative research projects. Education for Information, 22(2), 63-75.

Shin, H.-H., \& Kim, H.-N. (2010). Analysis of elementary teachers' and students' views about difficulties on open science inquiry activities. Elementary Science Education, 29(3), 262-276.

Stokes, L. C., \& Pankowski, M. L. (1988). Incidental learning of aging adults via television. Adult Education Quarterly, 38(2), 88-100. 
Sünkel, W. (2005). Phenomenology of classroom teaching [Phaenomenologie des unterrichts: Grundriss der theoretischen Didaktik] (M. Kwon, Trans.). Seoul: Hakjisa. (1996).

Webb, S. (2008). The effects of context on incidental vocabulary learning. Reading in a Foreign Language, 20(2), 232-245.

Woolnough, B. E. (2001). Of 'knowing science' and of 'doing science': A reaffirmation of the tacit and the affective in science and science education. Canadian Journal of Science, Mathematics and Technology Education, 1(3), 255-270. 